\section{Vol. 69, No. 47}

In the report "Trends in County-Level COVID-19 Incidence in Counties With and Without a Mask Mandate - Kansas, June 1-August 23, 2020," on p. 1777, the sixth footnote should have read "†† https://usafacts.org/visualizations/coronaviruscovid-19-spread-map. Accessed August 31, 2020.”

\section{Vol. 62, No. RR-1}

In the MMWR Recommendations and Reports "Methodology of the Youth Risk Behavior Surveillance System - 2013," the Republic of the Marshall Islands and the Republic of Palau were erroneously referred to as U.S. territories. Throughout the report, all references to "territories" should have read "territories and freely associated states," and all references to "territorial" should have read "territorial and freely associated state." 